EGU Stephan Mueller Special Publication Series, 1, 125-136, 2002

(C) European Geosciences Union 2002

\title{
Assumed Neogene deformation in the Central Western Carpathians as inferred from magnetic anisotropy investigations
}

\author{
F. Hrouda ${ }^{1,2}$, D. Plašienka ${ }^{3}$, and D. Gregorová ${ }^{4}$ \\ ${ }^{1}$ AGICO Inc., Brno, Czech Republic \\ ${ }^{2}$ Institute of Petrology and Structural Geology, Charles University, Praha, Czech Republic \\ ${ }^{3}$ Geological Institute, Slovak Academy of Sciences, Bratislava, Slovak Republic \\ ${ }^{4}$ Geophysical Institute, Slovak Academy of Sciences, Bratislava, Slovak Republic
}

Received: 23 February 2001 - Revised: 18 June 2001 - Accepted: 22 June 2001

\begin{abstract}
The Central Western Carpathians do not form a continuous mountain range, but crop out within the mostly unfolded Central Carpathian Palaeogene and Neogene basins as the so-called Core Mountains. Within most Core Mountains, the magnetic fabrics often are coaxial in metamorphic, granitic and covering sedimentary rocks, being partially or entirely deformational in origin. On the other hand, the orientations of the magnetic fabric differ between the individual Core Mountains. In addition, the Central Carpathian Palaeogene rocks show signs of increasing ductile deformation towards the NW margin of the Central West Carpathians. These phenomena are interpreted to result from young, probably Neogene, movements associated with the closure of neighbouring flysch basin.
\end{abstract}

\section{Introduction}

Anisotropy of magnetic susceptibility (AMS) is one of the most powerful tools for investigating the rock fabric. Modern instruments for its measurement are very sensitive, accurate, and rapid so that one can investigate even very weakly magnetic and very weakly anisotropic rocks of large collections of oriented specimens (measurement of one specimen takes about 2 minutes). In addition, the AMS can easily be measured both in crystalline and sedimentary rocks, offering thus an excellent basis for the investigation of the fabric relationships between nappe and cover sedimentary rocks, granitoid and metamorphic rocks of the crystalline complexes.

The Central Western Carpathians, unlike to the Alps and other mountain chains, do not create a continuous mountain range, but crop out in several inliers as the so-called Core Mountains within the mostly unfolded Central Carpathian Palaeogene and Neogene basins. In some Core Moun-

Correspondence to: F. Hrouda (agico@agico.cz) tains, for example the Branisko and Čierna Hora Mountains (Hrouda et al., 1988), Tatry Mountains (Hrouda and Kahan, 1991), Veporské vrchy Mountains (Hrouda et al., 2002), the magnetic fabric is deformational in origin, showing similar patterns in metamorphic, granitic and covering sedimentary rocks within each Core Mountains, but different orientations between the Core Mountains. This magnetic fabric is regarded as resulting from Alpine ductile deformation associated with metamorphism during Upper Cretaceous formation and motion of the Central West Carpathian nappes (Biely and Hrouda, 1992; Grabowski, 1996; Gregor et al., 1992a, b; Hrouda and Vozár, 1995; Hrouda et al., 2002) which strongly overprinted the older magnetic fabrics in all rock types.

In other Core Mountains, for example the Strážovské vrchy Mountains (Hrouda et al., 1983; Hrouda and Hanák, 1990) or the Malé Karpaty Mountains (Hrouda, 1986), the effect of the ductile deformation is much weaker and the magnetic fabrics in different rock types are in general not coaxial.

In the Central Carpathian Palaeogene formations, the magnetic fabric is essentially sedimentary in origin in the central area, the Liptov Depression, while it indicates an influence of increasing ductile deformation towards the NW margin of the Central Western Carpathians; it is partially deformational in the Skorušinské vrchy hills and almost entirely deformational in origin in the Zázrivá Depression (Hrouda and Potfaj, 1993).

The purpose of the present paper is to summarize all the AMS data of metamorphic and granitic rocks from the Central Western Carpathians, including also the unpublished data from the Považský Inovec Mountains, Malá Fatra Mountains, Nízke Tatry Mountains, Veporské vrchy Mountains, and Spišsko-gemerské rudohorie Mountains, and to interpret them in terms of post-Cretaceous deformation history of the Central Western Carpathians. 


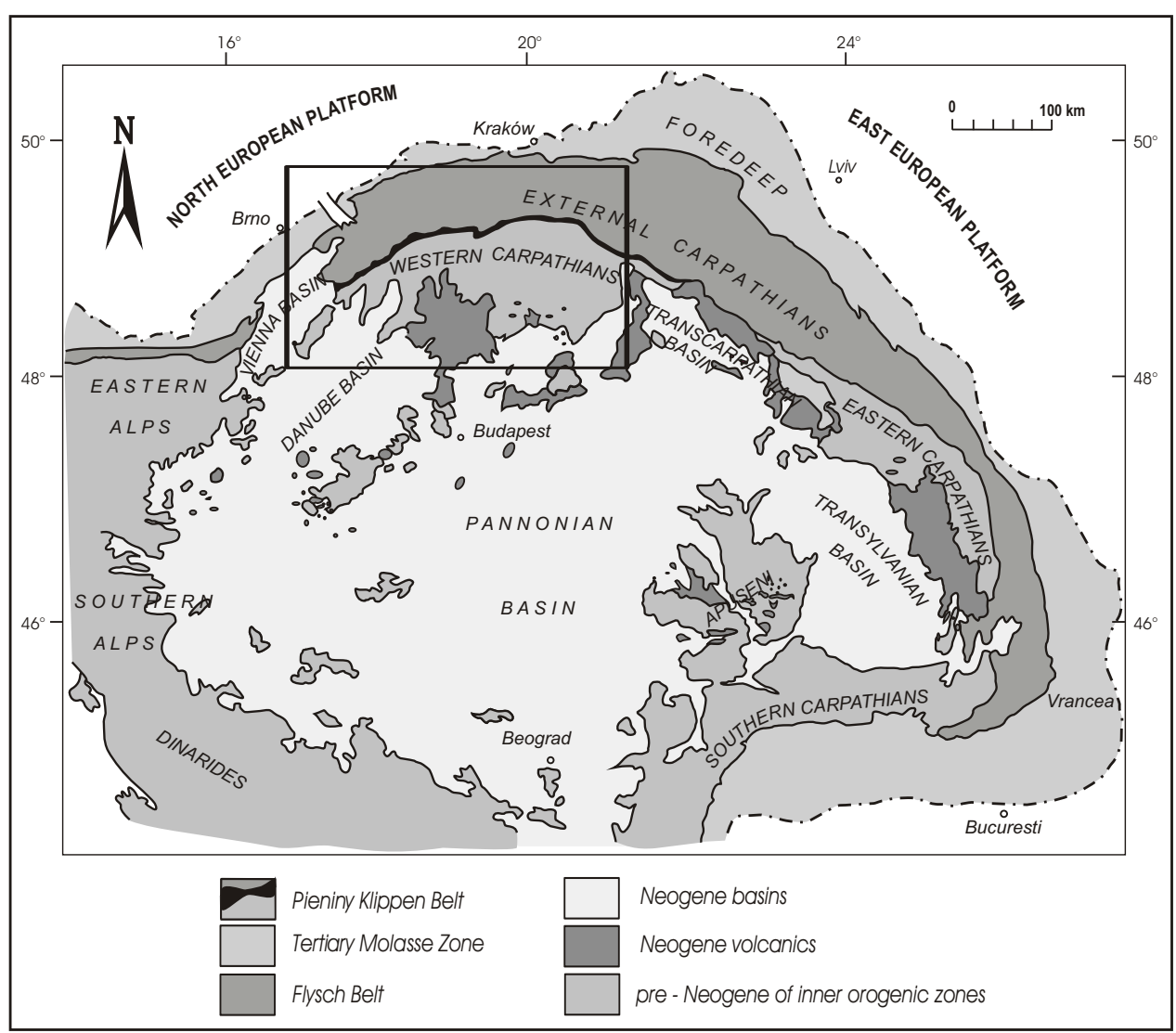

Fig. 1. Tectonic sketch of the Carpathian Mountains and the Pannonian Basin.

\section{Geological Setting}

The Western Carpathians constitute the northernmost, W-E trending branch of the European Alpides, linked to the Eastern Alps in the west and to the Eastern Carpathians in the east (Figs. 1, 2). The northern Carpathian foreland is formed by the North European Platform, including the basement consolidated during the Palaeozoic and the epi-Variscan platform cover of the Bohemian Massif and Polish Platform in the NW and N. This is separated by the Teisseyre-Tornquist Fault from the Fennosarmatian (Russian) Platform in the NE. The Alpine-Carpathian orogenic belt is unified into one system by the external zones of the Alpine and Carpathian foredeep (Molasse Zone) and by the Tertiary accretionary complexes composed mainly of imbricated Cretaceous to Palaeogene pelagic and turbiditic sequences (Flysch Belt). The Flysch Belt, including the Rhenodanubian-Magura, Outer Dacide and Silesian-Moldavide principal units, continues as an immense loop from the Eastern Alps up to the Vrancea region at the bend from the Eastern to the Southern Carpathians. Inside this loop, there is a collage of pre-Tertiary units that were assembled, split and reassembled several times during the Palaeozoic, Mesozoic and Tertiary (see Michalík and Kováč, 1982; Balla, 1984; Stampfli, 1996; Plašienka and Kováč, 1999; Willingshofer, 2000 and references therein). The Late Tertiary history of this area was governed by the subduction processes along the leading edge of the AlpineCarpathian orogenic system and by the back-arc extension of the upper Carpathian plate (e.g. Ratschbacher et al., 1991; Csontos et al., 1992; Csontos, 1995; Kováč et al., 1993, 1994, 1995, 1997; Plašienka et al., 1997a). Hinterland extension produced the large and complex Pannonian Basin and several rifting- and subduction-related volcanic chains that mostly obliterated the relationships of pre-Neogene tectonic units.

The narrow and long Pieniny Klippen Belt, marked by an intricate transpressional structure of Mesozoic and Palaeogene sediments, separates the Flysch Belt of the External Western Carpathians from the Central Western Carpathians. The Tertiary contractional processes in the External Western Carpathians only partly transmitted on the northern edge of the Central Western Carpathians, where they affected the Palaeogene sediments by transpression and backthrusting (e.g. Plašienka et al., 1998). The Central Western Carpathians are a system of paleo-Alpine (Cretaceous) nappe units comprising continental, pre-Alpine (Variscan) basement complexes and the Late Palaeozoic to Mesozoic sedimentary successions. Their units are generally well correlable to the Austroalpine nappe system of the Eastern Alps (e.g. Plašienka, 1995). To the South, units of the Internal Western Carpathians show close relationships to units 


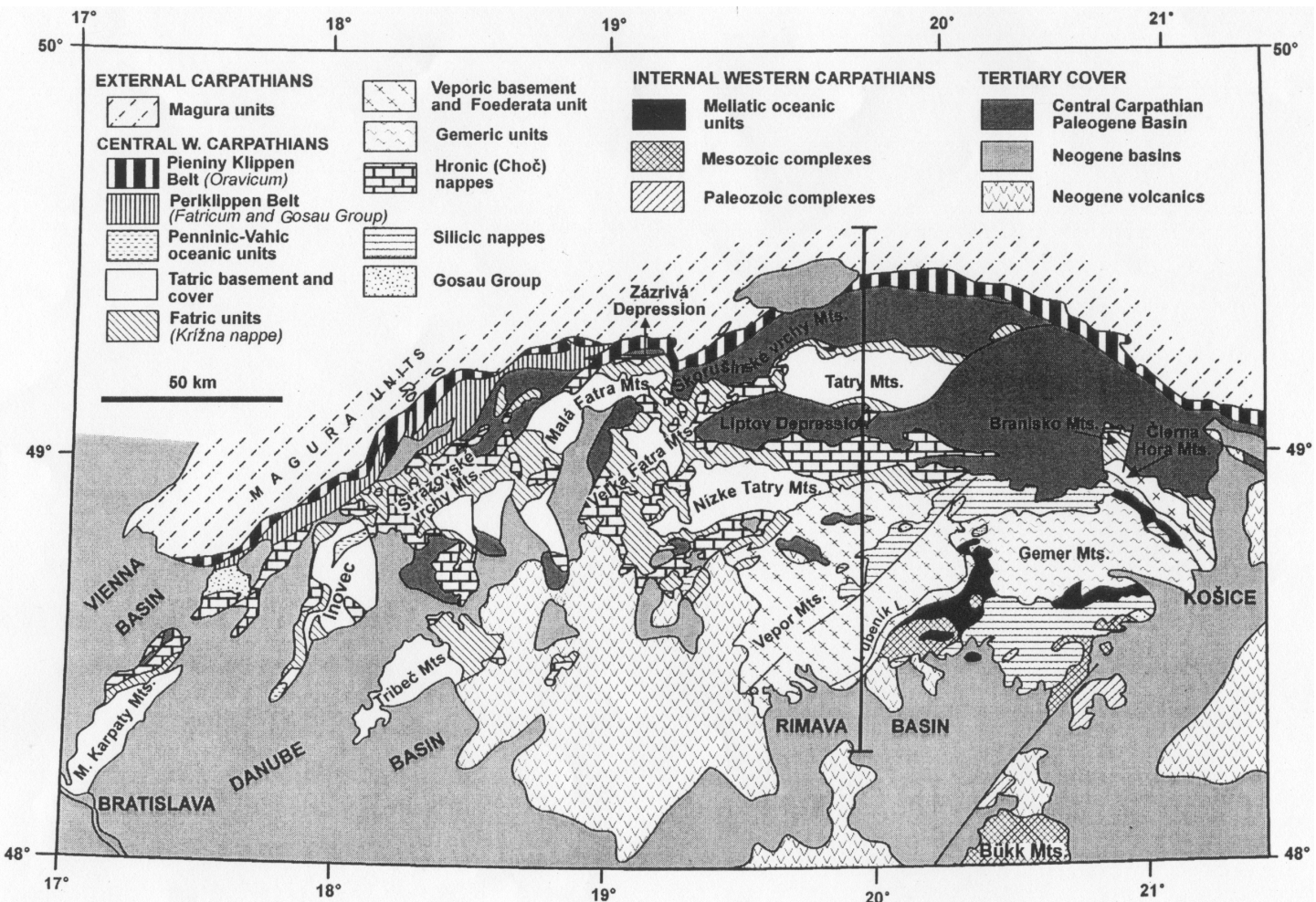

(a)

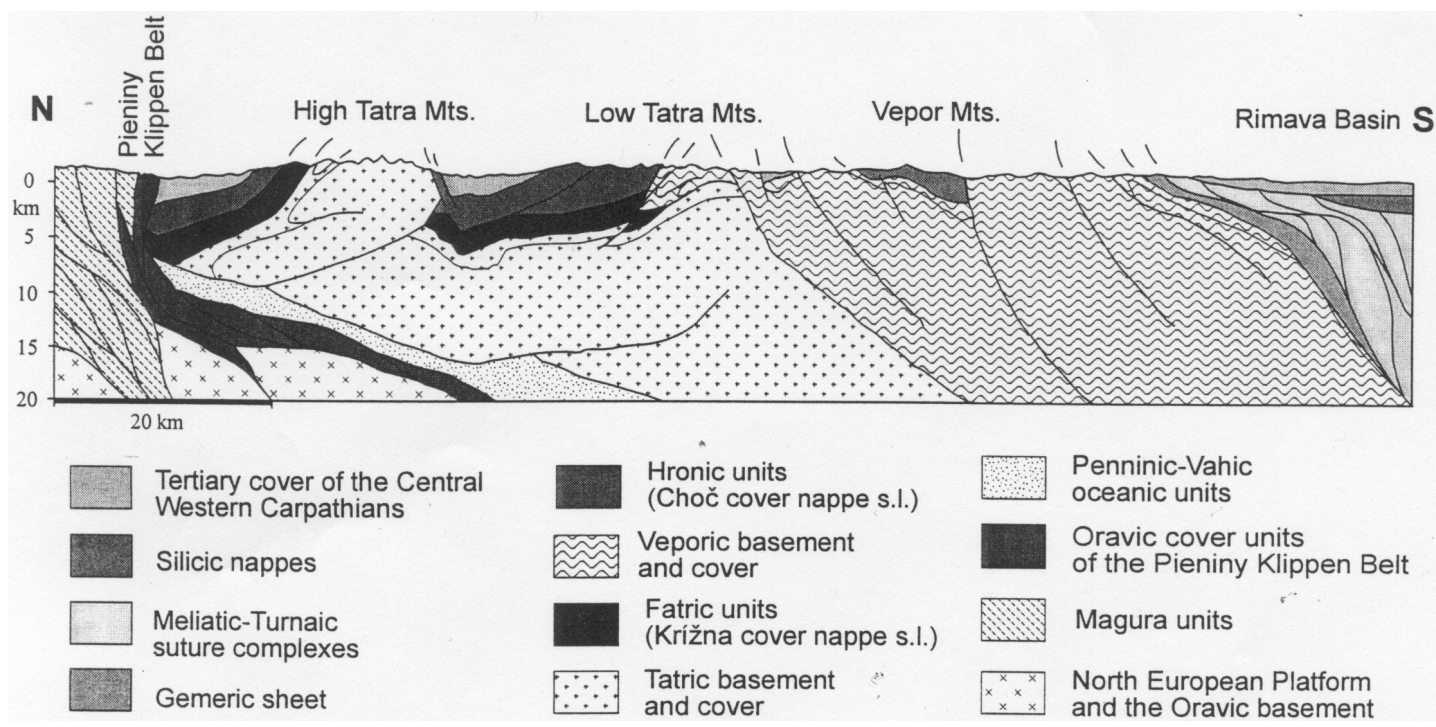

(b)

Fig. 2. (a) Simplified geological map of the western part of the Central Western Carpathians. (b) Schematic section through the Central Western Carpathians. For location see (a).

of the South Alpine-Dinaride orogenic system (e.g. Haas et al., 1995). The present structural pattern of the Central and Internal Western Carpathians was formed by the Late Jurassic - Tertiary subduction-collision orogenic processes in the Tethyan mobile belt between the stable North European Platform and drifting Apulia/Adria-related continental fragments. The boundary between the Central and Internal
Western Carpathians follows the Late Jurassic suture of the Triassic - Jurassic Meliata-Hallstatt oceanic realm, while the Pieniny Klippen Belt appears to be a surface expression of a suture after the Penninic-Vahic oceanic domain rifted during the Jurassic and closed during the Palaeogene (Plašienka et al., 1997a; see Figs. 2a, b). 

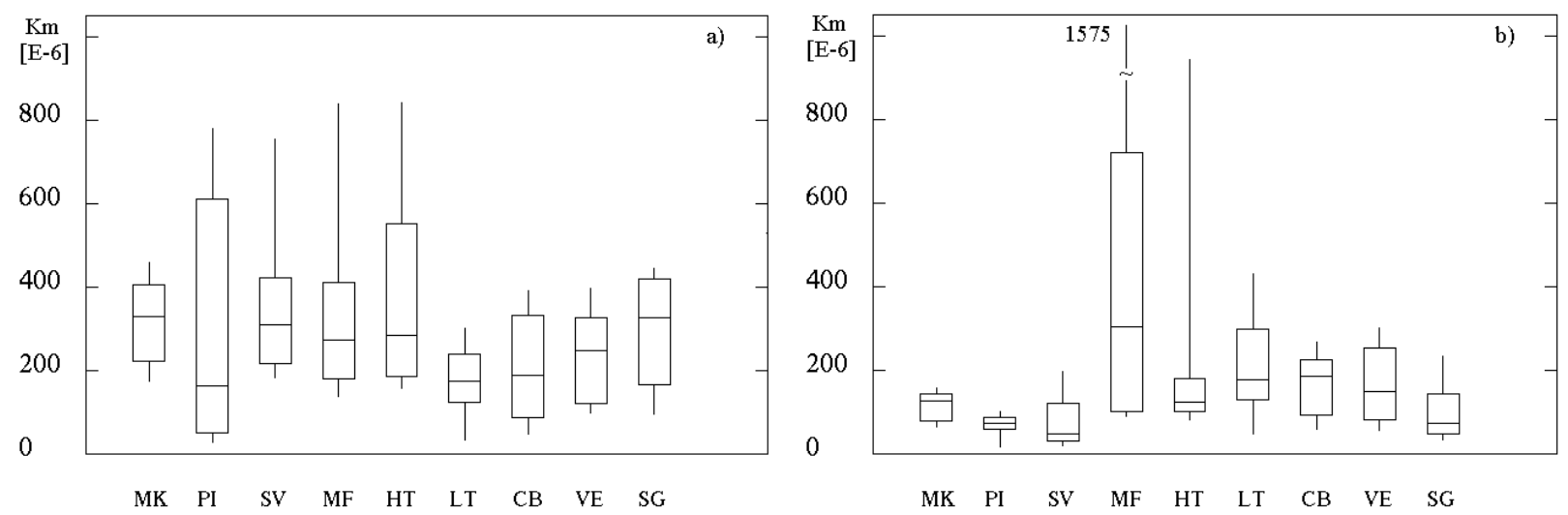

Fig. 3. Box-and-whisker plots of the mean bulk susceptibility in metamorphic (a) and granitic (b) rocks of the individual Core Mountains. Legend: MK - Malé Karpaty Mts., PI - Považský Inovec Mts., SV - Strážovské vrchy Mts., MF - Malá Fatra Mts., HT - High Tatra Mts., LT - Low Tatra Mts., CB - Čierna Hora and Branisko Mts., VE - Veporské vrchy Mts., SG - Spišsko-gemerské rudohorie Mts. The box-and-whisher plots graphically display the summary statistics of a data set (McGill et al., 1978; Tukey, 1977). The mean value is represented by the median being the central line in the central box. The central box covers the middle $50 \%$ of the data values, between the lower and upper quartiles. The "whiskers" extend out to extremes (minimum and maximum values), but only to those points that are within 1.5 times the interquartile range.
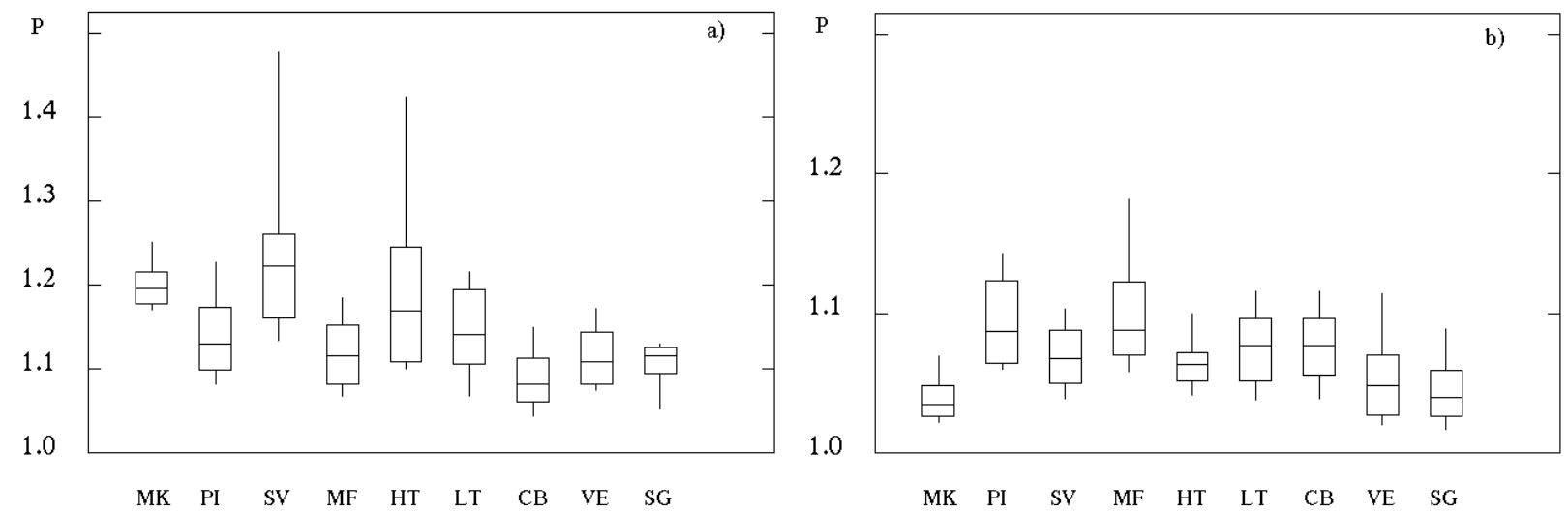

Fig. 4. Box-and-whisker plots of the degree of AMS $(P)$ in metamorphic (a) and granitic (b) rocks of the individual Core Mountains. For legend see Fig. 3.

\section{Measurement and processing techniques, data pre- sentation}

The AMS of oriented specimens was measured by the KLY-2 and KLY-3S Kappabridges (Jelínek, 1973, 1980; Jelínek and Pokorný, 1997) and computed using the ANISO 11-14 and SUSAR programs (Jelínek, 1977). In order to obtain a statistical evaluation of the AMS in individual localities and in whole geological bodies, the ANISOFT package of programs (Jelínek, 1978; Hrouda et al., 1990) was used, which enable a complete statistical evaluation of a group of specimens to be carried out.

The AMS data are represented by the $k_{m}, P$, and $T$ param- eters which are defined as follows:

$$
\begin{aligned}
& k_{m}=\left(k_{1}+k_{2}+k_{3}\right) / 3 \\
& P=k_{1} / k_{3} \\
& T=2 \ln \left(k_{2} / k_{3}\right) / \ln \left(k_{1} / k_{3}\right)-1
\end{aligned}
$$

where $\mathrm{k}_{1} \geq \mathrm{k}_{2} \geq \mathrm{k}_{3}$ are the principal susceptibilities. The $P$ parameter, called the degree of AMS, indicates the intensity of the preferred orientation of magnetic minerals in a rock and the $T$ parameter indicates the shape of the susceptibility ellipsoid. The $T$ parameter (Jelínek, 1981) varies from -1 (perfectly linear magnetic fabric) through 0 (transition 

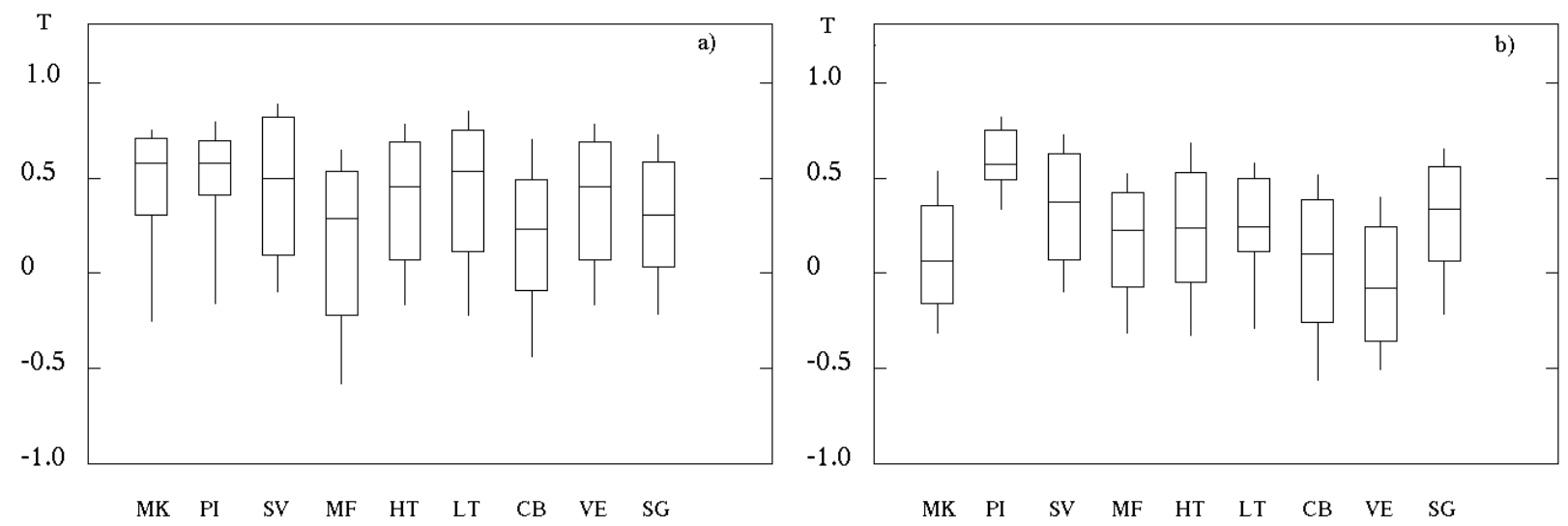

Fig. 5. Box-and-whisker plots of the shape parameter $(T)$ in metamorphic (a) and granitic (b) rocks of the individual Core Mountains. For legend see Fig. 3.

between linear and planar magnetic fabric) to +1 (perfectly planar magnetic fabric).

\section{Magnetic Mineralogy}

The magnetic susceptibility of both metamorphic and granitic rocks is relatively low in all the Core Mountains investigated (Figs. 3a, b). The susceptibility distribution in individual Core Mountains is clearly asymmetric with more frequent presence of more strongly magnetic specimens. In granitic rocks, the susceptibility is less variable, only in the Malá Fatra Mountains and the Tatry Mountains frequent specimens with relatively high susceptibilities occur.

The magnetic minerals carrying the AMS were investigated through measurement of the temperature variation of bulk susceptibility on powder specimens using the CS3 Apparatus and KLY-3S Kappabridge (Parma et al., 1993; Hrouda, 1994). These investigations have shown that the rock susceptibility is carried by paramagnetic minerals (mostly micas) and magnetite. In weakly magnetic rocks, the contribution of paramagnetic minerals is stronger than that of magnetite, in strongly magnetic rocks the susceptibility is carried by magnetite almost exclusively.

\section{Magnetic fabric}

In metamorphic rocks, the degree of AMS is moderate to relatively high and not too variable within individual Core Mountains and only slightly variable between the Core Mountains (Fig. 4a). It is slightly lower in the Veporic Zone than in the Tatric Zone. The magnetic fabric is predominantly planar in general, ranging from clearly planar to moderately linear within the individual Core Mountains and not differing very much between the Core Mountains (Fig. 5a). The magnetic fabric in the Veporic Zone is less planar than that in the Tatric Zone.

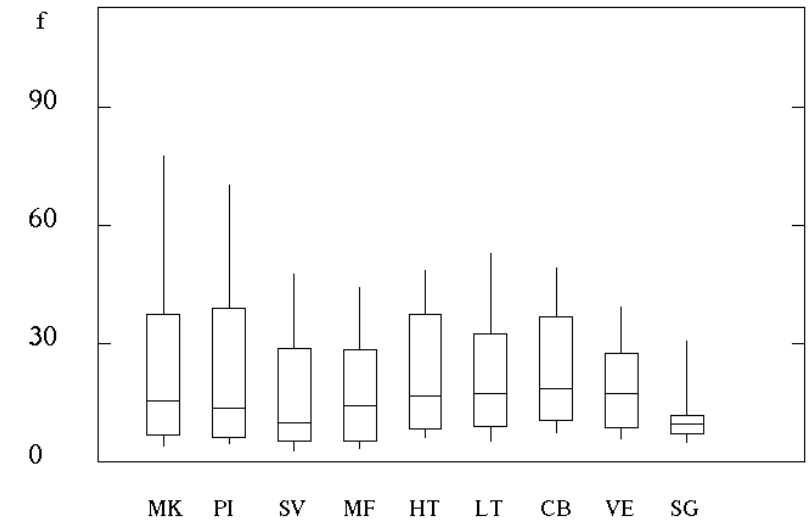

Fig. 6. Box-and-whisker plots of the angle $(f)$ between the magnetic foliation and metamorphic schistosity in metamorphic rocks of the individual Core Mountains. For legend see Fig. 3.

In granitic rocks, the degree of AMS is low to moderate not too variable within individual Core Mountains and only slightly variable between the Core Mountains (Fig. 4b). It is in general lower than that in metamorphic rocks. The magnetic fabric is slightly planar in general, ranging from moderately planar to moderately linear within the individual Core Mountains and not differing very much between the Core Mountains (Fig. 5b).

The magnetic foliations are roughly parallel to the metamorphic schistosity in the most specimens, but show large deviations from it in many specimens (Fig. 6). The patterns of magnetic foliations and magnetic lineations are very similar in metamorphic and granitic rocks in all the Core Mountains. Within each individual Core Mountains or a homogeneous body creating part of the Core Mountains, the magnetic foliation poles tend to create imperfect and wide girdles both in metamorphic and granitic rocks, while the magnetic lineation creates a large maximum roughly perpendicu- 

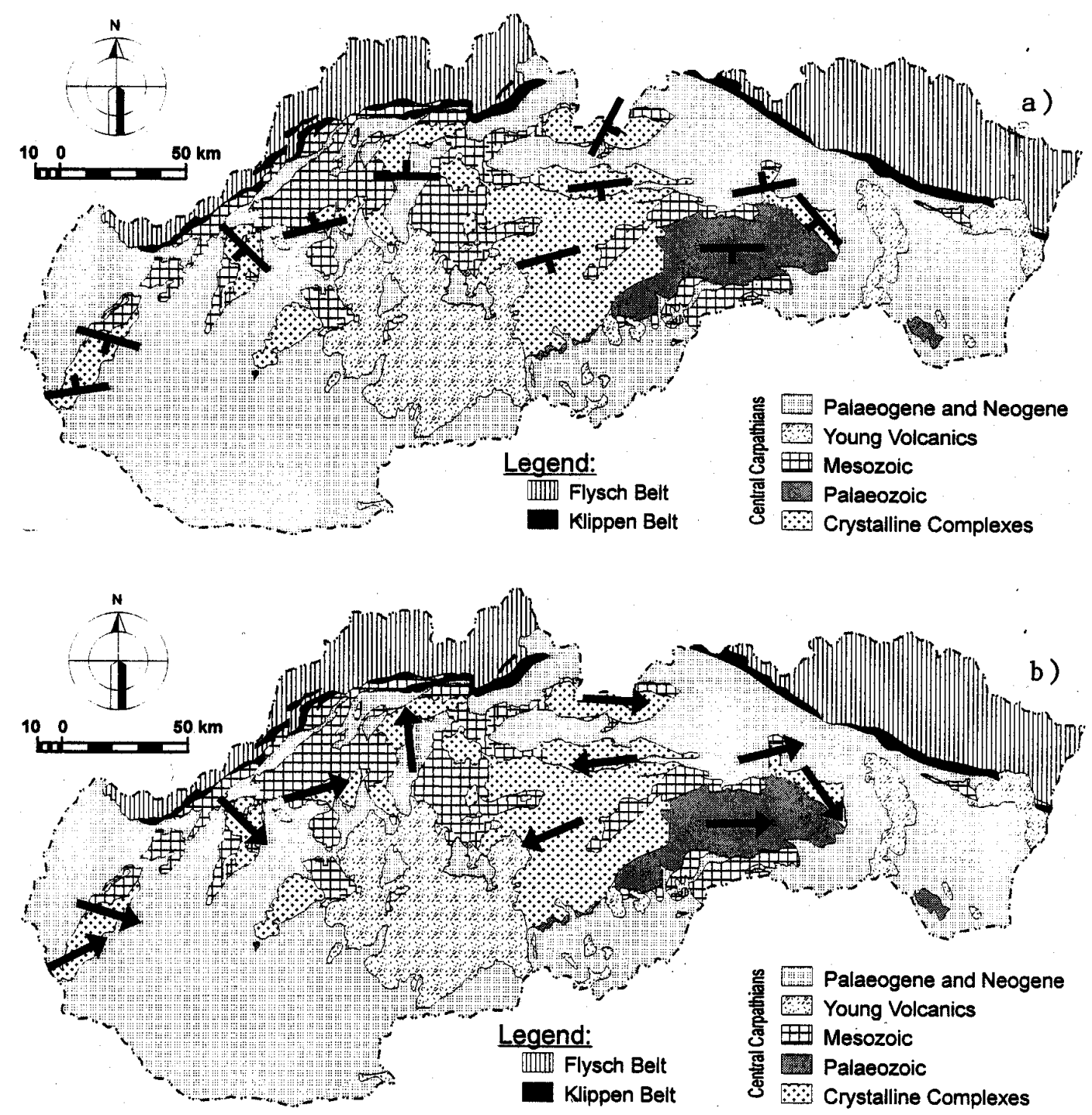

Fig. 7. Orientations of mean magnetic foliations (a), (c) and magnetic lineations (b), (d) for individual Core Mountains or their parts (bodies with homogeneous magnetic fabric) on the territory of Slovakia (delimited by the dot-and-dashed line) in metamorphic (a,b) and granitic (c, d) rocks (Fig. 7 continues.

lar to the girdle in magnetic foliation poles (for examples see Hrouda and Kahan, 1991; Hrouda et al., 1983, 1988, 2002).

Fig. 7 shows the orientations of mean magnetic foliations and magnetic lineations for individual Core Mountains or their parts (bodies with homogeneous magnetic fabric). It can be seen in the figure that the orientations of both the magnetic foliations and magnetic lineations are in general very different in the individual bodies.

The origin of the magnetic fabric in metamorphic and granitic rocks of the Veporic Zone was discussed by Hrouda et al. $(1988,2002)$ on the basis of comparison with the magnetic fabric in sedimentary rocks covering them. In the sedimentary rocks, the degree of AMS is variable, ranging from low to relatively high, untypical for sedimentary rocks. The magnetic fabric is also very variable, ranging from clearly linear to clearly planar. The magnetic foliations are parallel to the bedding in some specimens, but in most of them the angle between the magnetic foliation and bedding is moderate to large. The relatively low degree of AMS, planar magnetic fabrics, and small angle between the magnetic foliation and bedding in some specimens may indicate the depositional origin of the magnetic fabric, while the relatively high degree of AMS, predominantly prolate magnetic fabrics and moderate to very large angles between magnetic foliation and bedding (magnetic foliation is often almost perpendicular to bedding) in the most specimens no doubt indicate deformational effects on the magnetic fabric. Consequently, the magnetic fabric can be regarded in general as composite, i.e. composed of the tectonic magnetic fabric superimposed on the sedimentary magnetic fabric. This superimposition has a character of very strong overprinting up to obliteration of the sedimentary magnetic fabric.

The magnetic fabric in metamorphic rocks is planar only in a part of specimens, being clearly linear in many spec- 

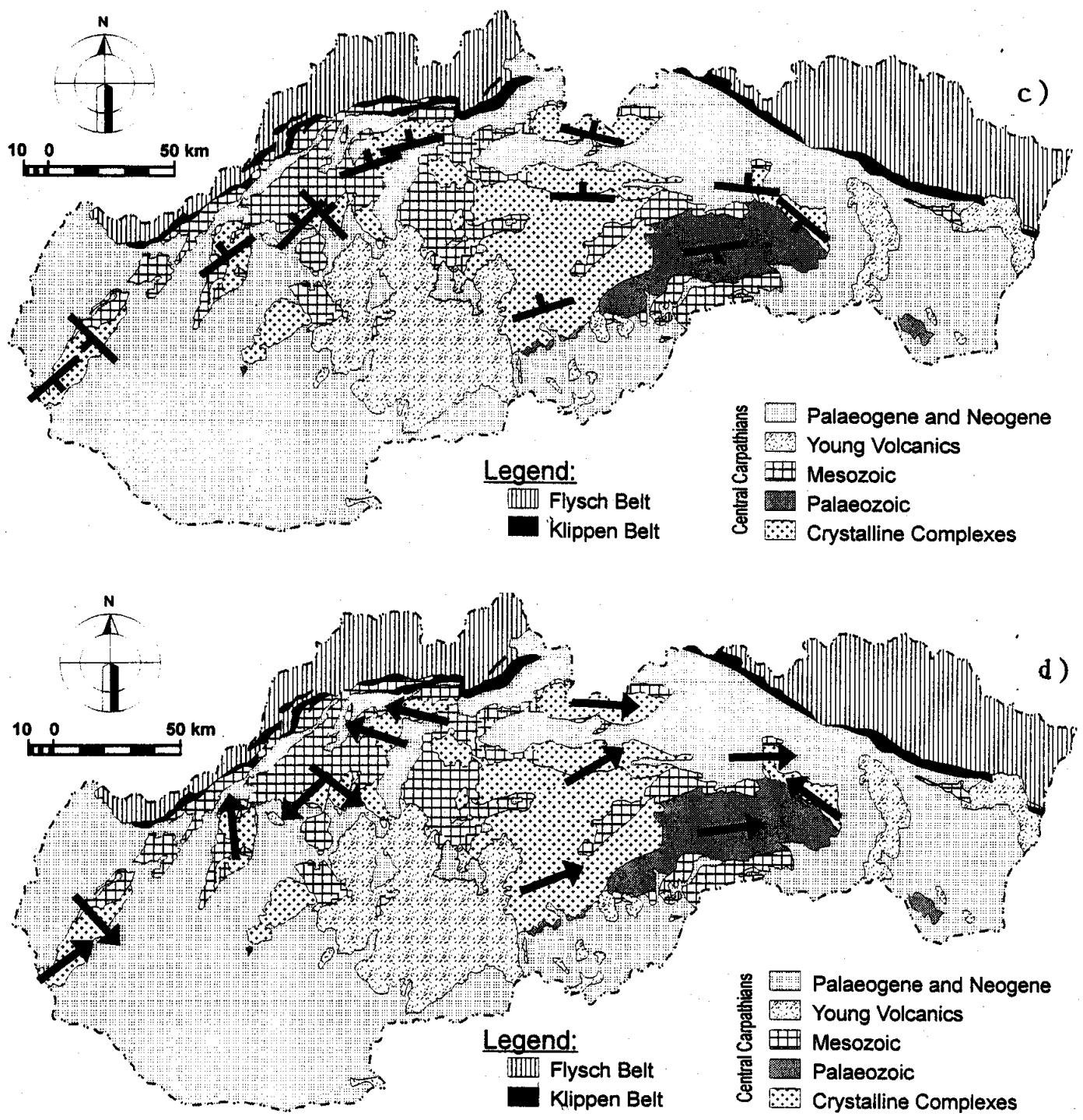

Fig. 7. ... continued.

imens. In addition, the magnetic foliations, even though roughly parallel to the main (Variscan) metamorphic schistosity in the most specimens, show large deviations from it in many specimens tending to create partial girdle in its poles. The magnetic foliations in these specimens are near the Alpine mesoscopic foliations (for details see Hrouda et al., 2002). One can deduce that the magnetic fabric in metamorphic rocks originated only partially during the process of the Variscan progressive metamorphism. The specimens with clearly deviating magnetic foliation from the metamorphic schistosity probably indicate effects of ductile deformation associated with Alpine retrogressive metamorphism.

The Veporic Zone granites are mostly massive, showing no fluidal fabric, but showing mylonitic schistosity in some places. The magnetic foliation is roughly parallel to the mylonitic schistosity and the magnetic fabric is roughly coaxial with that in the surrounding metamorphic rocks and with that of deformed sedimentary rocks. Consequently, one can de- duce that the magnetic fabric in the Veporic Zone granitic rocks is rather deformational than intrusive in origin.

Plašienka et al. (1999) characterize the metamorphic and tectonic history of the Veporic Zone as follows:

"The Veporic basement and its Permian-Mesozoic cover experienced mediumpressure, collision-related metamorphism during the Cretaceous. Geothermobarometric calculations of Alpine mineral assemblages indicate peak conditions of $8-12 \mathrm{kbar}$ and $550-600^{\circ} \mathrm{C}$ in the deepest exposed basement, and up to $8 \mathrm{kbar}$ and $450-500^{\circ} \mathrm{C}$ in the Permian metasediments. After having reached the metamorphic peak conditions (at around $110 \mathrm{Ma},{ }^{40} \mathrm{Ar} /{ }^{39} \mathrm{Ar}$ on amphiboles), the thermally softened Veporic unit was exhumed probably due to underplating of a buoyant Tatric-Fatric crust. Exhumation was triggered by extensional denudation of former upper-crustal thrust units, overlying the Veporic unit. 

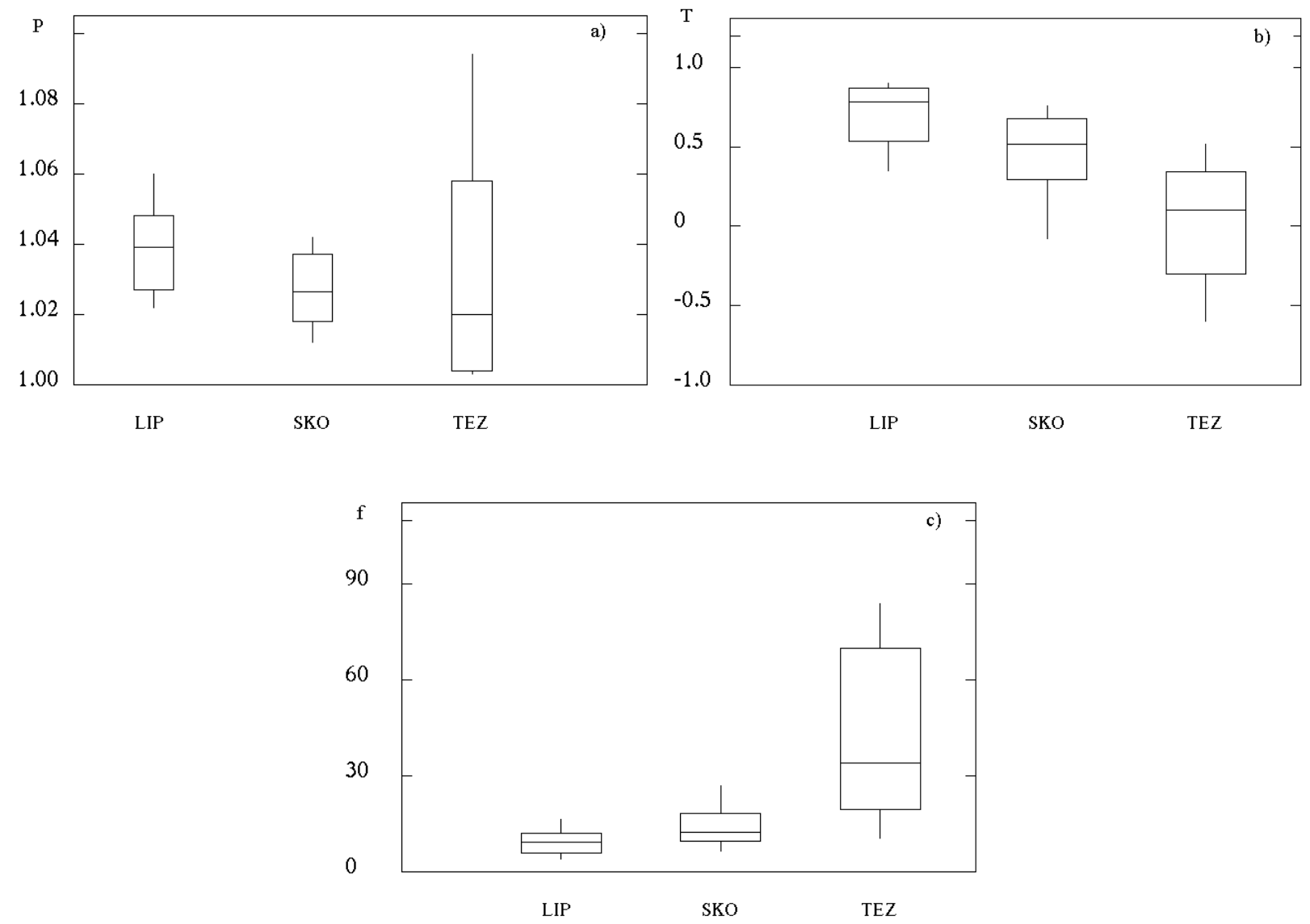

Fig. 8. Box-and-whisker plots of the degree of AMS (a), the shape parameter (b), and the angle between magnetic foliation and bedding (c) for the Central Carpathian Palaeogene. Legend: LIP - Liptov Depression, SKO - Skorušinské vrchy Mts., TEZ - Zázrivá Depression.

Unroofing was accomplished due to orogen-parallel, top-to east extension along low-angle, ductile normal shear zones. The area collapsed and rapidly cooled at $90-80 \mathrm{Ma}\left({ }^{40} \mathrm{Ar} /{ }^{39} \mathrm{Ar}\right.$ on micas). As revealed by structural record, the doming and tectonic exhumation of the Veporic core occurred in an overall contractional regime and was followed by additional Late Cretaceous-Early Tertiary shortening events."

As the magnetic fabrics in metamorphic and granitic rocks are coaxial with the deformational magnetic fabrics of the Permian-Mesozoic sediments covering them, it is likely that their formation took place during the above described Cretaceous metamorphism. The originally strong metamorphic and granitic rocks were softened due to metamorphism and underwent ductile deformation which gave rise to coaxial magnetic fabrics in metamorphic, granitic and sedimentary rocks.

In some Core Mountains of the Tatric Zone (e.g. Tatry Mountains - Fig. 2a) the magnetic fabrics in metamorphic, granitic, and sedimentary rocks covering them are also coaxial as in the Veporic Zone. The origin of the magnetic fabric in these Core Mountains is probably the same as that in the
Veporic Zone, described above. In the other Core Mountains (Strážovské vrchy Mountains, Považský Inovec Mountains, Malá Fatra Mountains, Nízke Tatry Mountains), the relationship between the magnetic fabrics of the various rock types is more complex. Sometimes the magnetic fabric in the metamorphic and granitic rocks are coaxial, but that in the sedimentary rocks is non-coaxial. In the others, the magnetic fabrics in metamorphic, granitic, and sedimentary rocks are non-coaxial. This magnetic fabric indicates that the influence of the Cretaceous deformations is relatively weak.

In the Liptov Depression of the Central Carpathian Palaeogene basin, the degree of AMS is relatively high and the magnetic fabric is clearly planar in almost all the specimens investigated (Fig. 8a, b). The magnetic foliations are near the bedding (Fig. 8c). This magnetic fabric can be regarded as essentially sedimentary in origin.

In the Skorušinské vrchy hills, the degree of AMS is lower than in the Liptov Depression, but its scatter is slightly larger (Fig. 8a). The magnetic fabric is variable, but predominantly planar; in several specimens, however, the magnetic fabric is linear (Fig. 8b). The magnetic foliation is still near the bedding in the majority of specimens, but the angle between 
the magnetic foliation and bedding is in general larger than in the Liptov Depression (Fig. 8c). This magnetic fabric can be regarded as partially influenced by deformation.

In the Zázrivá Depression, the degree of AMS is mostly very low, even though some specimens show very high degree of AMS (Fig. 8a). The magnetic fabric varies widely from purely planar to purely linear (Fig. 8b). The angle between magnetic foliation and bedding ranges from very small to very large, reaching almost 90 degrees in some specimens (Fig. 8c). This magnetic fabric can be classified as strongly affected by ductile deformation.

\section{Discussion and conclusions}

As shown earlier, the intensity and symmetry of the magnetic fabric are relatively homogeneous within individual Core Mountains and only slightly variable between the Core Mountains. However, the magnetic fabric orientation is also relatively homogeneous within individual Core Mountains, but very different between the Core Mountains. The magnetic fabric is partially to entirely deformational in origin. In addition, the magnetic fabrics show different orientations not only between the Core Mountains, but also within a Core Mountains if this is composed of two partial bodies. For example, in the Branisko and Čierna Hora Core Mountains the magnetic fabric orientation differs in the Branisko body and in the Čierna Hora body (for detailed AMS data see Hrouda et al., 1988). A similar situation is in the Strážovské vrchy Core Mountains where the magnetic fabric orientation differs in the Suchý Massif and Malá Magura Massif (Hrouda et al., 1983), and in the Malé Karpaty Core Mountains where the magnetic fabrics differs in the Bratislava Massif area and the Modra Massif area (Hrouda, 1983). Surprisingly, this is not the case of the Malá Fatra Core Mountains, where the magnetic fabrics are oriented in the same way in the Lúčna body and in the Kriván body, even though the orientations of the mesoscopic fabric elements differ in these two bodies.

Similar results are shown also by palaeomagnetism. Unfortunately, the palaeomagnetic data are not sufficient for the analysis of the rotations of individual Core Mountains. Nevertheless, it is clear from them that the orientations of the characteristic directions of the remanent magnetization for the sediments covering the basement vary from one Core Mountains to another (Krs et al., 1982; Snopko and Tunyi, 1982; Vozárová and Muška, 1984; Grabowski and Nemčok, 1999). It is likely that these differences originated during young rotations that were different in various Core Mountains. In addition, Tertiary remagnetizations of the Palaeozoic rocks have been identified (Kruczyk et al., 2000) indicating Tertiary tectonic activities in the Central Western Carpathians.

Understanding the above differences in the magnetic fabric orientation can come from the deformational history of the Central Western Carpathians known from the other methods and presented below. The Central Western Carpathians consist of numerous nappe units, principally of the crustal-scale basement/cover nappe sheets (Tatric, Veporic and Gemeric superunits) and detached cover nappes (Fatric, Hronic and Silicic systems). As revealed by structural relationships and deep reflection seismic lines (e.g. Tomek, 1993), the thick-skinned, basement-involved units are stacked along moderately south-dipping thrust planes. At the surface, the higher Veporic and Gemeric sheets are cropping out in a comparatively coherent landmass, while exposures of the lowermost Tatric superunit appear as individual Core Mountains (Fig. 2a). The Core Mountains in the west (the Malé Karpaty, Považský Inovec, Tribeč, Strážovské vrchy and Malá Fatra Mountains) form elongated elevations some $10-15 \mathrm{~km}$ wide and about $30-50 \mathrm{~km}$ long, separated by the Neogene basins forming the northern embayments of the large Pannonian Basin system. These Core Mountains originated as horst structures during the Late Tertiary to Quaternary extension and transtension (Kováč et al., 1994). In the north-central part, separated from the western part by the NS trending central Slovakian wrench fault system (Kováč and Hók, 1993), the Vel'ká Fatra, Nízke Tatry and Tatry (High Tatra) Core Mountains seem to be essentialy compressional basement uplifts surrounded by Palaeogene deposits, but uplifted also during the Neogene and Quaternary.

In contrast to the Alps, the inner zones of the Carpathians did not suffer collisional processes during the Tertiary and their Late Alpine evolution was governed by extrusion tectonics (Ratschbacher et al., 1991; Nemčok, 1993; Decker and Peresson, 1996) and back-arc extension associated with sedimentary basin formation (Csontos et al., 1992; Horváth, 1993; Tari et. al., 1996). Consequently, the Tatric sheet, as the lowermost Austroalpine unit exposed in the Carpathians, does not provide insight into the deeper structure of the Central Western Carpathians. There are no large exposures of underlying Penninic units like in the Alps, where they were exhumed from below the Austroalpine units due to strong Tertiary collision and crustal thickening. Nevertheless, the northernmost parts of the Tatric basement sheet in a close proximity to the Pieniny Klippen Belt are in places underlain by a unit exhibiting Upper Jurassic - Cretaceous oceanic lithologies comparable to the Alpine South Penninic complexes (Plašienka et al., 1994, 1997a, b; Plašienka, 1995). The subsurface Inačovce-Krichevo unit drilled in the substratum of the Neogene East Slovakian Basin, south of the Pieniny Klippen Belt, was also correlated with the Alpine Penninic units (Soták et al., 1994) and interpreted as a Late Tertiary metamorphic core complex exhumed during crustal extension. These occurrences indicate that oceanic Penninic units continue to the Western Carpathians, but are mostly overridden by the Tatric basement sheet. Based on the deep reflection seismic line 2T, Tomek (1993) considered the Tatric superunit as an about $10 \mathrm{~km}$ thick sheet overriding a highly reflective low-angle zone interpreted as a South Penninic (Ligurian-Piemont) oceanic suture. Therefore it seems highly probable that the entire Tatric sheet is underplated by strongly deformed oceanic complexes of the South Penninic (Vahic in the Carpathian terminology - Mahel, 1981) suture (Fig. 2b). 
The rheological contrast between the strong, upper crustal Tatric basement sheet and the underlying, weak sedimentary and melange oceanic Penninic-Vahic rocks was most probably utilized also during the Late Tertiary extension. Upper crustal complexes were stretched brittlely producing highangle and listric normal faults bounding the elevated horsts of core mountains and subsiding intervening Neogene basins (Fig. 2b). On the other hand, the middle and lower crustal complexes behaved ductilely during the Neogene extension, hence accommodating substantial crustal thinning and attenuation. At present, the crustal thickness reaches only 22$25 \mathrm{~km}$ below the most stretched parts of Neogene basins. The presence of a weak crustal horizon in the depths of $10-15 \mathrm{~km}$ below the mechanically strong Tatric sheet enabled its splitting into rigid extensional blocks, which in transtensional regime might have been tilted and rotated.

The degree of AMS and the magnetic fabric shapes are relatively homogeneous in all the bodies investigated both in metamorphic and granitic rocks. Consequently, it is very unlikely that the stress and strain fields controlling the formation of the magnetic fabric had more or less the same magnitudes in all the Core Mountains, but different orientations of the principal directions in each Core Mountains. Rather, it seems us more probable that the orientation of the magnetic fabric was rather homogeneous originally in each superunit and only later, during splitting the superunits (mainly the Tatric one) into rigid extensional blocks under extensional regime, tilting and rigid body rotations of smaller segments took place, the magnetic fabric was differentiated in orientation as observed today. This idea is also supported by the AMS data from sediments of the Central Carpathian Palaeogene Basin. The magnetic fabric in the marginal areas of the Central Carpathian Palaeogene Basin is partially to entirely deformational in origin which indicates the existence of Neogene deformations within the Central West Carpathians. In the Neogene, when the Flysch Belt of the Western Carpathians was folded and thrust, the Central Western Carpathians experienced only less intense deformations. These deformations were represented by rigid body rotations in strong metamorphic and granitic rocks and ductile deformations in soft Central Carpathian Palaeogene rocks.

Acknowledgements. The research whose results are used in the present paper was supported financially by the following institutions: Dionýz Štúr State Geological Survey of the Slovak Republic (Principal Investigators Drs. B. Leško and T. Koráb, F.H.), VEGA Slovak Grant Agency for Science (grant \#1137, D. P.), Geophysical Institute of Slovak Academy of Sciences (grant \#2/5136/98 to Dr. I. Túnyi, D. G.) and the Ministry of Education of the Czech Republic (grant \#2431 3005, F.H.).

\section{References}

Andrusov, D., Bystrický, J., and Fusán, O.: Outline of the structure of the West Carpathians. Guidebook for Geological Excursions, Dionýz Štúr Institute of Geology, Bratislava, 1973.

Balla, Z.: The Carpathian loop and the Pannonian basin: a kinematic analysis, Geophys. Transact., 30, 313-353, 1984.
Behrmann, J. H., Stiasny, S., Milička, J., and Pereszlényi M.: Quantitative reconstruction of orogenic convergence in the northeast Carpathians, Tectonophysics, 319, 111-127, 2000.

Biely, A. and Hrouda, F.: Magnetic fabric in Inner West Carpathian rocks and its Post-Cretaceous rearrangements, TERRA abstracts, supplement No. 2 to TERRA nova, 4, 9, Graz, 1992.

Csontos, L.: Tertiary tectonic evolution of the Intra-Carpathian area: a review, Acta Vulcanol., 7, 1-13, 1995.

Csontos, L., Nagymarosy, A., Horváth, F., and Kováč, M.: Tertiary evolution of the Intra-Carpathian area: a model, Tectonophysics, 208, 221-241, 1992.

Decker, K. and Peresson, H.: Tertiary kinematics in the Alpine Carpathian - Pannonian system: links between thrusting, transform faulting and crustal extension, in: Wessely, G. and Liebl, W. (Eds): Oil and gas in Alpine thrustbelts and basins of central and eastern Europe, EAGE Spec. Publ., 5, 69-77, 1996.

Grabowski, J.: Magnetic fabric of the Upper Jurassic sediments, Krížna unit, Tatra Mts., Poland, Geol. Carpath., 47, 331-337, 1996.

Grabowski, J. and Nemčok: Summary of Palaeomagnetic Data from the Central West Carpathians of Poland and Slovakia: Evidence for the Late Cretaceous - Early Tertiary Transpression, Phys. Chem. Earth (A), 24, 8, 681-685, 1999.

Gregor, T., Hrouda, F., Chlupáčová, M., and Stránska, M.: Magnetic anisotropy and natural radioactivity in West Carpathian granites, TERRA abstracts, supplement No. 2 to TERRA nova, 4, 26, 1992a.

Gregor, T., Hraško, L., and Hrouda, F.: West Carpathian granites: mainly post-intrusive magnetic fabrics, Supplement to EOS Trans, AGU, April 7, 283, 1992b.

Haas, J., Kováčs, S., Krystyn, L., and Lein, R., Significance of Late Permian - Triassic facies zones in terrane reconstructions in the Alpine - North Pannonian domain, Tectonophysics, 242, 19-40, 1995.

Horváth, F.: Towards a mechanical model for the formation of the Pannonian basin, Tectonophysics, 226, 333-357, 1993.

Hrouda, F.: Fabric implications of magnetic anisotropy measurements of rocks of the Malé Karpaty (Little Carpathians) Mts. (SW Slovakia), Annuaire Inst. Geol. Geophys., Bucharest, 63, 57-61, 1983.

Hrouda, F.: The magnetic fabric of sedimentary rocks of the Malé Karpaty Mts. and its tectonic implications. Sbor. geol. Věd, řada UG, 20, 165-167, 1986.

Hrouda, F.: A technique for the measurement of thermal changes of magnetic susceptibility of weakly magnetic rocks by the CS-2 apparatus and KLY-2 Kappabridge, Geophys. J. Int., 118, 604612, 1994.

Hrouda, F. and Hanák, J., Magnetic fabric of sedimentary formations of the Strážovské vrchy Mts., sedimentological and tectonic implications, Sbor. geol. Věd, řada UG, 24, 91-105, 1990.

Hrouda, F. and Kahan, Š.: The magnetic fabric relationship between sedimentary and basement nappes in the High Tatra Mts. (N Slovakia), J. Struct. Geol., 13, 431-442, 1991.

Hrouda, F. and Potfaj, M.: Deformation of sediments in the postorogenic Intra-Carpathian Paleogene Basin as indicated by magnetic anisotropy, Tectonophysics, 224, 425-434, 1993.

Hrouda, F. and Vozár, J.: Tectonic interaction between the Internides and Centralides of the Inner West Carpathians, as indicated by magnetic anisotropy, Jour. Czech Geol. Soc., 40/3, 67, 1995.

Hrouda, F., Kahan, S., and Putiš, M.: The magnetic and mesoscopic fabrics of the crystalline complex of the Strážovské vrchy 
Mts. and their tectonic implications, Geol. Carpath., 34, 717$731,1983$.

Hrouda, F., Jacko, S., and Hanák, J.: Parallel magnetic fabrics in metamorphic, granitoid and sedimentary rocks of the Branisko and Čierna Hora Mountains (E Slovakia) and their tectonometamorphic control, Phys. Earth Planet. Inter., 51, 271-289, 1988.

Hrouda, F., Jelínek, V., and Hrušková, L.: A package of programs for statistical evaluation of magnetic anisotropy data using IBMPC computers, EOS Trans. AGU. Fall meeting 1990, 1990.

Hrouda, F., Putiš, M., and Madarás, J.: The Alpine overprint of the magnetic fabric of Palaeozoic rocks of the Vepor Mts. (Central Slovakia), Tectonophysics (in press), 2002.

Jelínek, V.: Precision A. C. bridge set for measuring magnetic susceptibility of rocks and its anisotropy, Studia geophys. geod., 17, 36-48, 1973.

Jelínek, V.: The statistical theory of measuring anistropy of magnetic susceptibility of rocks and its application, Geofyzika, s.p. Brno, 1977.

Jelínek, V.: Statistical processing of magnetic susceptibility measured on groups of specimens, Studia geophys. geod., 22, 50-62, 1978.

Jelínek, V.: Kappabridge KLY-2. A precission laboratory bridge for measuring magnetic susceptibility of rocks (including anisotropy), Leaflet, Geofyzika Brno, 1980.

Jelínek, V.: Characterization of magnetic fabric of rocks, Tectonophysics, 79, T63-T67, 1981.

Jelínek, V. and Pokorný, J.: Some new concepts in technology of transformer bridges for measuring susceptibility anisotropy of rocks, Phys. Chem. Earth, 22, 179-181, 1997.

Kováč, P. and Hók, J.: The Central Slovak fault system - the field evidence of a strike slip, Geol. Carpath., 44, 155-159, 1993.

Kováč, M., Marko, F., and Nemčok, M.: Neogene structural evolution and basin opening in the Western Carpathians, Geophys. Transact., 37, 297-309, 1993.

Kováč, M., Král', J., Márton, E., Plašienka, D., and Uher, P.: Alpine uplift history of the Central Western Carpathians: geochronological, paleomagnetic, sedimentary and structural data, Geol. Carpath., 45, 83-96, 1994.

Kováč, M., Kováč, P., Marko, F., Karoli, S., and Janočko, J.: The East Slovakian Basin - a complex back arc basin, Tectonophysics, 252, 453-466, 1995.

Kováč, M., Bielik, M., Lexa, J., Pereszlényi, M., Šefara, J., Túnyi, I., and Vass, D.: The Western Carpathian intramountane basins: in: Grecula, P., Hovorka, D., and Putiš, M. (Eds): Geological evolution of the Western Carpathians, Mineralia Slov. Monogr., Bratislava, 43-64, 1997.

Krs, M., Muška, P., and Pagáč, P.: Review of Palaeomagnetic Investigations in the West Carpathians of Czechoslovakia, Geologické práce, Správy 78, 39-58, 1982.

Kruczyk, J., Kadzialko-Hofmokl, M., Jelenska, M., Túnyi, I., Grecula, P., and Návesnák, D.: Tectonic and structural implications of palaeomagnetic and AMS study of highly metamorphosed palaeozoic rocks from the Gemeric Superunit, Slovakia, Geologica Carpathica, 51, 133-144, 2000.

Mahel', M.: Island character of Klippen Belt; Vahicum - continuation of Southern Penninicum in West Carpathians, Geol. Zbor. Geol. Carpath., 32, 293-305, 1981.

McGill, R., Tukey, J. W., and Larsen, W. A.: Variation of box plots, American Statistician, 32, 12-16, 1978.

Michalík, J. and Kováč, M.: On some problems of palinspastic reconstructions and Meso-Cenozoic paleogeographical development of the Western Carpathians, Geol. Zbor. - Geol. Carpath.,
33, 481-507, 1982.

Nemčok, M.: Transition from convergence to escape: field evidence from the West Carpathians, Tectonophysics, 217, 117-142, 1993.

Nemčok, M., Nemčok, J., Wojtaszek, M., Ludhová, L., Klecker, R. A., Sercombe, W. J., Coward, M. P., and Keith Jr., J. F.: Results of $2 \mathrm{D}$ balancing along $20^{\circ}$ and $21^{\circ} 30^{\prime}$ longitude and pseudo-3D in the Smilno tectonic window: Implications for shortening mechanisms of the West Carpathian accretionary wedge, Geol. Carpath., 51, 281-300, 2000.

Parma, J., Hrouda, F., Pokorný, J., and Wohlgemuth, J. et al.: A technique for measuring temperature dependent susceptibility in weakly magnetic rocks. Supplement to EOS Trans, AGU, 113, Washington, 1993.

Plašienka, D.: Passive and active margin history of the northern Tatricum (Western Carpathians, Slovakia), Geol. Rundschau, 84, 748-760, 1995.

Plašienka, D. and Kováč, M.: How to loop the Carpathians - an attempt to reconstruct Meso-Cenozoic palinspastic history of the Carpathian orocline, Geol. Carpath., 50, spec. issue, 163-165, 1999.

Plašienka, D., Janák, M., Lupták, B., Milovský, R., and Frey, M.: Kinematics and metamorphism of a Cretaceous Core Complex: the Veporic Unit of the Western Carpathians, Phys. Chem. Earth (A), 24, 651-658, 1999.

Plašienka, D., Marschalko, R., Soták, J., Peterčáková, M., and Uher, P.: Origin and structural position of Upper Cretaceous sediments in the northern part of the Považský Inovec Mts. Part 1: Lithostratigraphy and sedimentology (in Slovak, English summary), Mineralia Slov., 26, 311-334, 1994.

Plašienka, D., Grecula, P., Putiš, M., Kováč, M., and Hovorka, D.: Evolution and structure of the Western Carpathians: an overview, in: Grecula, P., Hovorka, D., and Putiš, M. (Eds): Geological evolution of the Western Carpathians, Mineralia Slov., Monogr., 1-24, 1997a.

Plašienka, D., Havrila, M., Michalík, J., Putiš, M., and Reháková, D.: Nappe structure of the western part of the Central Carpathians, in: Plašienka, D., Hók, J., Vozár, J., and Eléčko, M. (Eds.): Alpine evolution of the Western Carpathians and related areas, Internat. conf., Introduct. articl. exc., Geol. Survey Slov. Rep. - D. Štúr Publ., Bratislava, 139-161, 1997b.

Plašienka, D., Soták, J., and Prokešová, R.: Structural profiles across the Šambron-Kamenica Periklippen Zone of the Central Carpathian Paleogene Basin in NE Slovakia, Mineralia Slov., 29, 173-284, 1998.

Ratschbacher, L., Frisch, W., Linzer, H. G., and Merle, O.: Lateral extrusion in the Eastern Alps, Part 2: Structural analysis, Tectonics, 10, 257-271, 1991.

Roca, E., Bessereau, G., Jawor, E., Kotarba, M., and Roure, F.: PreNeogene evolution of the Western Carpathians: Constraints from the Bochnia-Tatra section (Polish Western Carpathians), Tectonics, 14, 855-873, 1995.

Roure, F., Roca, E., and Sassi, W.: The Neogene evolution of the outer Carpathian flysch units (Poland, Ukraine and Romania): kinematics of a foreland/fold-and-thrust belt system, Sediment. Geol., 86, 177-201, 1993.

Snopko, L. and Túnyi, I.: Palaeomagnetical characteristics of selected Early Paleozoic rock types of the Gemericum (in Slovak), Geologické práce, Správy 78, s. 11-38, 1982.

Soták, J., Spišiak, J., and Biroň, A.: Metamorphic sequences with "Bündnerschiefer" lithology in the pre-Neogene basement of the East Slovakian Basin, Mitt. Österr. Geol. Ges., 86 (1993), 111120, 1994. 
Stampfli, G. M.: The Intra-Alpine terrain: A Paleotethyan remnant in the Alpine Variscides, Eclogae Geol. Helv., 89, 13-42, 1996.

Tari, G., Horváth, F., and Rumpler: J. Styles of extension in the Pannonian Basin, Tectonophysics, 208, 203-219, 1992.

Tomek C.: Deep crustal structure beneath the central and inner West Carpathians, Tectonophysics, 226, 417-431, 1993.

Tukey, J. W.: Exploratory data analysis. Reading, Mass: AddisonWesley, 1977.
Vozárová, A. and Muška, P.: Palaeomagnetic study results of Crystalline Complex and Upper Palaeozoic Formations in south-west part of the Malá Fatra Mts. (in Slovak), Geologické práce, Správy 81, 183-193, 1984.

Willingshofer, E.: Extension in collisional orogenic belts: the Late Cretaceous evolution of the Alps and Carpathians, Vrije Univ., Amsterdam, 146p, 2000 